\title{
TAXONOMICAL REVISION OF CONULARIIDS IN THE COLLECTION OF THE MUSEO NACIONAL DE CIENCIAS NATURALES (CSIC), MADRID (SPAIN)
}

\author{
C. Sendino* \& C. Santos**
}

\section{ABSTRACT}

C. Sendino \& C. Santos. 2011. Taxonomical revision of conulariids in the collections of the Museo Nacional de Ciencias Naturales (CSIC), Madrid (Spain). Graellsia, 67(1): 13-21.

This work is a taxonomical revision of conulariids (Scyphozoa) in the collection of the Museo Nacional de Ciencias Naturales (CSIC). Much of the collection comprises Ordovician samples from the Parque Nacional de Cabañeros (Castilla-La Mancha). Specimens have been redetermined and chemically analysed and some are shown not to be conulariids.

Key words: Taxonomical revision; collection; conulariids; Parque Nacional de Cabañeros; Museo Nacional de Ciencias Naturales (CSIC).

\section{RESUMEN}

C. Sendino \& C. Santos. 2011. Revisión taxonómica de los conuláridos en la colección del Museo Nacional de Ciencias Naturales (CSIC), Madrid (España). Grael/sia, 67(1): 13-21 (en inglés).

Este trabajo recoge la revisión taxonómica de la colección de conuláridos (Scyphozoa) del Museo Nacional de Ciencias Naturales (CSIC). Esta colección esta formada básicamente por muestras ordovícicas del Parque Nacional de Cabañeros (Castilla-La Mancha). Se han redeterminado y analizado químicamente los ejemplares, con lo que algunos de los mismos se han excluido del grupo.

Palabras clave: Revisión taxonómica; colección; conuláridos; Parque Nacional de Cabañeros; Museo Nacional de Ciencias Naturales (CSIC).

\section{Introduction}

The Museo Nacional de Ciencias Naturales (CSIC) houses the best conulariid collection maintained in a Spanish or Portuguese museum, as well as the largest collection of Iberian specimens in any museum, with a total of 23 specimens. This is a critical source of data for comparing fauna from different palaeocontinents in order to check recent palaeogeographical reconstructions for the Ordovician period.

The collection was partly published in a previous paper (Sendino, 2007a) in which most of these conulariids were determined. In this new study we have omitted some specimens that were published as conulariids because of their similarity to conu-

* Dep. Palaeontology, Natural History Museum, Cromwell Road, London SW7 5BD, UK. c.sendino-lara@nhm.ac.uk

** Colecciones de Invertebrados fósiles y Paleobotánica, Museo Nacional de Ciencias Naturales, Agencia Estatal CSIC, c/ José Gutiérrez Abascal 2, 28006 Madrid, España. csantos@mncn.csic.es 
lariids steinkerns but do not belong to this group as shown by chemical analyses of shell remnants. The new identifications have led to a redistribution of specimens in the MNCN palaeontology collection.

\section{Material and methods}

To begin with we have compiled data from bibliographical references on collections globally in order to find out which museum or private collection houses the most representative collection of Iberian conulariids and also which geological period is best represented.

Thirty eight specimens catalogued as conulariids in MNCN collection have been revised, studied and chemically analyzed. The nomenclature has been updated, checking the previous determinations when given, and updating them. When we believed specimens to be incorrectly determined as conulariids, we asked specialists on other groups for advice about their true identities. This proved very useful in one specimen previously determined as Hyolithes Eichwald, 1840, and later as a "conulariid-like" fossil. The specimens that were thought to be conulariids are preserved as steinkerns resembling inverted pyramids, even having a conulariidlike square cross-section in several cases. After a more detailed study of these specimens using optical microscope and SEM (scanning electron microscopy) coupled with an Energy Dispersive Xray Analysis system to determine elemental composition, they can be identified as pterioid bivalves. In several specimens the remnants of shell material helped to identify the specimens.

At the same time, we have studied the original as well as the most recent labels and have checked all information available in card files and the old register of specimens of the MNCN (AMNCN CN0239/001, CN0239/002). We have also revised two bibliographical resources about the history of the paleoinvertebrates collection from MNCN (Barreiro, 1992; Montero, 2003), in order to find acquisition dates. Unfortunately, in spite of our efforts, in some cases we could not obtain complete specimen information. Some of the specimens have precise locality data but most, especially the old ones, only record the province where they were collected. The trend in all world scientific collections is to have better data with specimens, even coordinates, in contrast to older times.

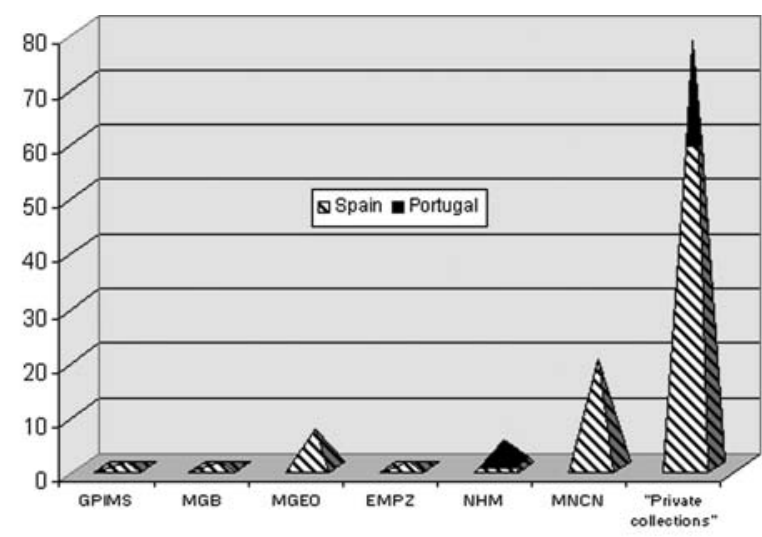

Fig. 1.- Percentage of lberian conulariids in different collections and bibliographical citations.

Fig. 1.- Porcentaje de conuláridos ibéricos en las diferentes colecciones y citas bibliográficas.

\section{Results and discussion}

IBERIAN CONULARIIDS IN WORLD MUSEUMS

More than 13,200 conulariid specimens are cited in the bibliographical references, of which only 142 are Iberian (123 Spanish, 23 Portuguese -some of these ones appear in Spain as well-). These Iberian specimens are kept in the following institutions: the Geologisch-Paläeontologisches Institut der Universität Münster [GPMS] (1 Spanish); Museo de Geología de Barcelona [MGB] (1 Spanish); Museo Geominero [MGEO] (7 Spanish); Museo Paleontológico de Zaragoza [EMPZ] (1 Spanish); the Natural History Museum, London [NHM] (1 Spanish, 4 Portuguese); and the Museo Nacional de Ciencias Naturales (CSIC) [MNCN] (20 Spanish). In addition, 59 Spanish and 19 Portuguese specimens cited in geological studies, such as those of Delgado (1897, 1908), Hernández Sampelayo (1915, 1931, 1942a y 1942b) and Kindelán (1918) were apparently kept in private collections and are now impossible to locate (Fig. 1).

Most classical studies on this scyphozoan group do not give the exact place where the specimens were collected, citing normally only the province. Some specimens from other museum record only the Iberian country where they were collected. Such poor information means that the specimen cannot be useful in palaeobiogeographical or stratigraphical studies. 


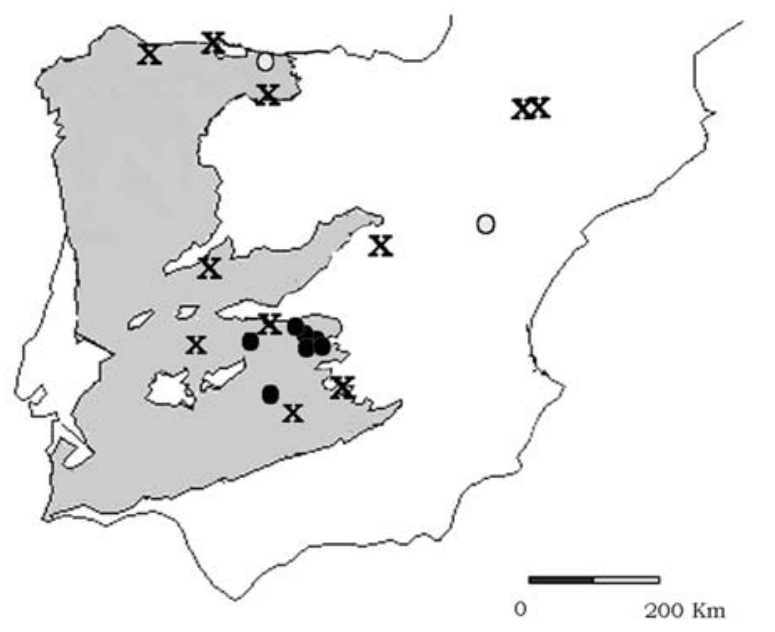

Hesperian Massi

Sites with specimens at the MNCN

Sites with specimens from other museums and "private collections" $\mathbf{X}$ Sites cited in bibliographical references

Fig. 2.- Conulariid sites in the Iberian Peninsula.

Fig. 2.- Yacimientos con conuláridos en la Península lbérica.

Although conulariid fossils are "rare" at many localities, almost 55 genera and 400 species are known from around the world. Some conulariid species are locally abundant enough to have lent their name to particular geological units, e.g. the Conularia-Sandstone in the Upper Ordovician of Jordan. Unfortunately, however, conulariids are scarce in the Iberian Peninsula (Fig. 2).

\section{IBERIAN CONULARIIDS AT THE MNCN (CSIC)}

The Museo Nacional de Ciencias Naturales (CSIC) maintains 23 specimens in its conulariid collection. When we started to study this collection, there were ten samples of corals and bryozoans, one hyolithid and three bivalves included, as well as a plastic mould of a "conulariid" donated by Dolores Gil Cid (Universidad Complutense) that we have omitted from our inventory. This mould resembles a pseudoconulariid, but the distance between the supposed longitudinal ridges is about 5 $\mathrm{mm}$, very far from the size of an authentic pseudoconulariid. We have tried to find the location of the original, but this must have been lost in the works carried out in 2007 at the Facultad de Ciencias Geológicas in the Universidad Complutense. If it had been a conulariid, it would have been the largest (estimated at more than one metre) of any

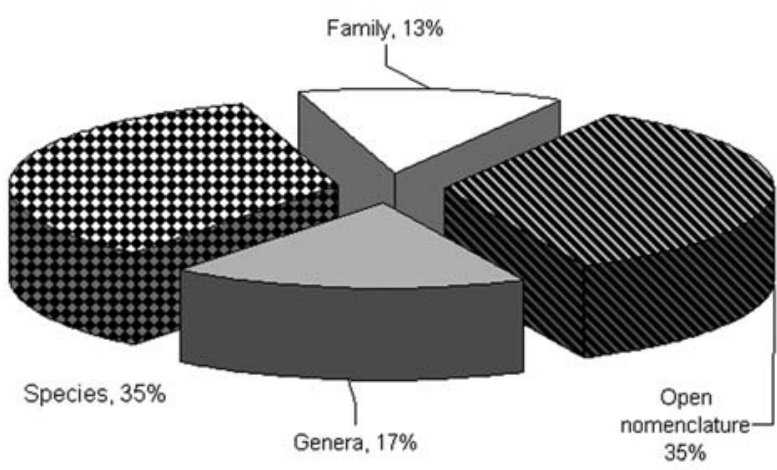

Fig. 3.- Level of determination for conulariids in the MNCN (CSIC) collections.

Fig. 3.- Niveles de determinación de los conuláridos en las colecciones del MNCN (CSIC).

described during two centuries of conulariid research. This almost certainly belongs to another group of organisms.

All the conulariid specimens kept at the MNCN (CSIC) belong to the family Conulariidae Walcott, 1886, one the six families of the order Conulariida Miller \& Gurley, 1896. There are at least four genera and seven species. The catalogued specimens from the Central Iberian Zone belong to four genera and five species, plus an additional three species in open nomenclature (Bengtson, 1988). Most specimens are contemporary with Bohemian conulariids and do not differ taxonomically (Barrande, 1867; Bouček, 1928, 1939; Želizko, 1900, 1901, 1902, 1903, 1905, 1906a, 1906b, 1907a, 1907b, 1909a, 1909b, 1911a, 1911b, 1913, $1918,1921)$. Ten of the conulariid specimens have been determined to species level, the remainder to genus or family level, or have been left in open nomenclature (Fig. 3). These belong to four genera: Archaeoconularia Bouček, 1939, Metaconularia Foerste, 1928, Exoconularia Sinclair, 1952 and Pseudoconularia Bouček, 1939. Metconularia? consobrina (Barrande, 1867) is considered to be a junior synonym of Metaconularia? pyramidata (Bronn, 1837).

Apart from two American (MNCNI-37798 and MNCNI-37799) and one French sample (MNCNI04948), the collection comprises entirely Spanish material. Not every specimen has stratigraphical and geographical data recorded; thus we only now with certainty that 20 specimens are Iberian. 


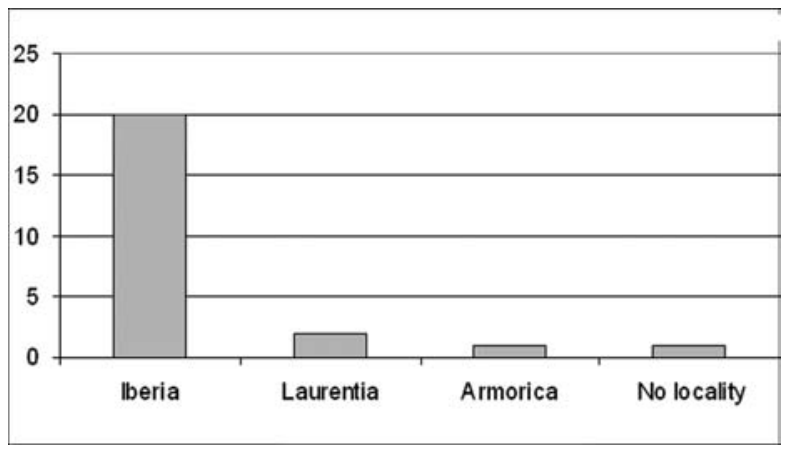

Fig. 4.- Percentage of the conulariids in the MNCN (CSIC) Collection according to locality.

Fig. 4.- Porcentaje de conuláridos en la Colección del MNCN (CSIC) según su procedencia.

Iberian conulariids are better represented, with more than double the number of specimens, at the MNCN (CSIC) than any other museum. All these Iberian specimens are from the Ordovician of the Hesperian Massif. There are also two from Laurentia (Elgin, Fayette County, Iowa), one from Armorica (May, Calvados, France) and probably another from the Bohemian Basin (possibly from Mt Dravob, Czech Republic) (Fig. 4). Material cited in publications or in private collections contain one only or a few specimens each.

Three out of twenty specimens are preserved as internal and external moulds within siliceous nodules. This preservation is typical for the Pizarras con Neseuretus Formation in Montes de Toledo (Central-Southern Spain) where invertebrate fossils (Ausich et al., 2002; Rábano, 1985, 1989; Gutiérrez-Marco et al., 1985, 1999, 2002) are normally found as natural casts in shales. Ten specimens are from at least eight different sites in Navas de Estena, Las Ventas con Peña Aguilera, Retuerta del Bullaque and Almadén (see Rábano, 1989 for locality details). All occur in shale. Six isolated samples from Navas de Estena are from an unknown locality (four of these have the same record number, MNCNI-20563; the others are numbered MNCNI-13575 and MNCNI-13576). They occur in shales of dissimilar lithologies and represent at least two different taxa. Associated with these conulariids is a great variety of organisms such as trilobites, graptolites, molluscs, brachiopods, echinoderms and bryozoans. These taxa are found in exclusively marine sediments (apart from molluscs) and may indicate very rapid sedimentation. Of seven samples from Retuerta del Bullaque, five come from the same locality. The taxa present are Exoconularia? sp. Exoconularia exquisita (Barrande, 1867), Exoconularia cf. exquisita (Barrande, 1867), and Pseudoconularia cf. klouceki (Bouček, 1928). Except for Exoconularia? sp. and Pseudoconularia cf. klouceki (Bouček, 1928), they occur in nodules. Sedimentation was similar to the previous specimens, and the associated fauna is the same because the specimens are in shale, as is usual for Retuerta del Bullaque. The other specimen is from Las Ventas con Peña Aguilera, also from the Darriwilian, and has a similar associated fauna and lithology. The last specimen is from Almadén. The precise locality is unknown. This is in shale too, but not as fine grained as the previous ones. The precise locality is unknown. It is associated with graptolites (Monograptus Geinitz, 1852) and Hyolithes on the same slab.

Some of the Spanish conulariids are contemporary with Czech and French faunas. Their association with other coeval conulariids is considered to be related to the palaeogeography of the time. But, it is important to consider the possible influences of small sample size and palaeoenvironmental adaptations at this time. There are two species and three genera shared between Montes de Toledo, the Armorican Massif and he Prague Basin. This similarity of conulariid genera argues against palaeogeographical isolation.

Although we have to be aware of the attachment of the conulariids to a substrate during some part of the life cycle, they spent part of their life cycle unattached. Thus, there are close affinities between the EAP (Exoconularia - Archaeoconularia - Pseudoconularia) cool-water conulariid province (Van Iten \& Vyhlasová, 2004) with Montes de Toledo; the first and the third of these genera in addition to Metaconularia are characteristic of this province. This is consistent with current palaeogeographical reconstructions for the Ordovician period.

Between the three non-Iberian specimens, there is a genus and a species that has not been recorded in this peninsula. But the Laurentia fauna is very different from the Gondwana fauna in the Palaeozoic.

The collection includes samples that were purchased from the end of the $19^{\text {th }}$ century to the beginning of the $21^{\text {th }}$ century (Fig. 5). A lot of the 


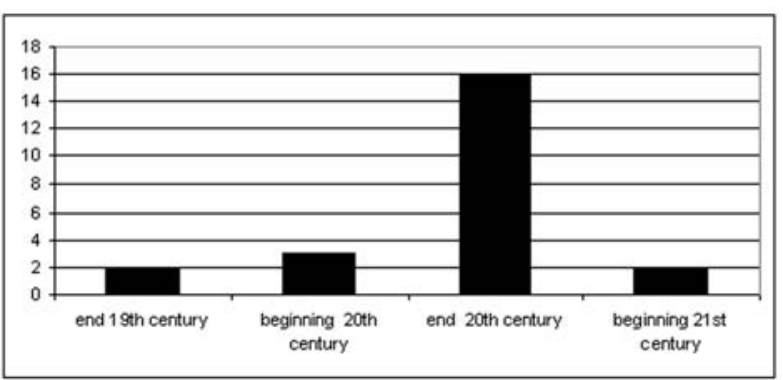

Fig. 5.- Historical origin of the conulariid specimens from the MNCN (CSIC).

Fig. 5.- Origen de los ejemplares de conuláridos del MNCN (CSIC).

specimens were collected and donated by the palaeontologist Ángel Montero between 1989 and 1993, with 15 specimens from Ordovician palaeontological sites in Ciudad Real and Toledo. The collection includes some specimens with historical value too. This historical value is demonstrated, at least, by one specimen from the end of the $19^{\text {th }}$ century, from the Comptoir Geologique de Paris, which was purchased when this geological dealership was located at 15 rue de Tournon (Montero, 2003; Wilson, 2010). There is also a specimen from Almadén without collection date, whose label is like the other specimens which were purchased at the end of the $19^{\text {th }}$ century. From this locality, there were two registered entrances at that time (Montero, 2003). One of them in 1874, from a trip of Solano y Eulate, and another later one in 1884 by Federico Botella, but this specimen is not registered in the respective lists of the revised income books (AMNCN CN0239/001, CN0239/002).

Most of the other historical specimens were collected by José Royo y Gómez (1895-1961), Joaquín Gómez de Llarena y Pou (1891-1979) and Gabriel Martín Cardoso (1896-1954), well-known Spanish geologists who were prolific collectors of fossils in the early twentieth century and whose collections are considered to be the core of the $\mathrm{MNCN}$ (Barreiro, 1992; Montero, 2003; Perejón \& Gomís, 2005).

One specimen donated at the beginning of the 1980s, came from the Leo Imperatori collection, a Spanish industrial engineer who was an amateur geologist. This specimen resembles Ordovician and Silurian material of Bohemia specimens, although the Leo Imperatori collection mostly comes from the Palaeolithic of the Iberian Peninsula. Unfortunately, this specimen does not have details of the site, only Stratigraphy which is Lower Palaeozoic (?Ordovician).

Appendix 1 includes the complete inventory of conulariids housed at the MNCN (CSIC). A list of genera and species are presented in alphabetical order. The specimens have been ordered by inventory-number within each species. Each specimen is recorded according to that inventory number, which is formed by the museum acronym (MNCN), "I-" referring to fossil invertebrate collection and finally a number with five digits. Stratigraphy, site, collection, acquisition date and bibliographical reference are stated if the information is available. In case of "collection" we refer to the fossil collector or the origin of the sample. Stratigraphy and site data are given from minor to major entity.

\section{Conclusions}

Not all the specimens previously catalogued as conulariid in the MNCN (CSIC) collection were well identified. This inventory gives updated and revised determinations of the 23 specimens of conulariids from the MNCN (CSIC) collection.

In spite of its small size, this is the best collection of Iberian conulariids in the world. The category private collections refers to the sum of all specimen citations in publications or private collections, that contain each one a few samples.

All specimens come from the Ordovician of the Hesperian Massif. As a result, this collection is a key to research on Iberian conulariids and can be useful for palaeobiogeographical reconstructions in comparison with other Ordovician faunas from Gondwana. The geographic distribution of conulariids at different northern Gondwana localities during the Darriwilian stage, including the Iberian samples, has implications for plate configurations, supporting current palaeogeographical reconstructions for the Ordovician period. This collection is also compared with other Spanish material in collections elsewhere in the world. The Iberian conulariid fauna is compatible with the most recent palaeogeographical reconstructions.

The MNCN (CSIC) collection has a historical value. It was started at the end of the $19^{\text {th }}$ century and the latest samples recorded recently were 
donated only a few years ago. Historical specimens from the end of $19^{\text {th }}$ and the beginning of $20^{\text {th }}$ centuries include those from the Comptoir Geologique de Paris and the Royo, Cardoso and Llarena collections. Nevertheless, the most important collector is Dr. Ángel Montero with 15 specimens from different palaeontological sites in Ciudad Real and Toledo.

\section{Acknowledgements}

This preliminary study was supported by SYNTHESYS grant ES-TAF-651: Taxonomy of Spanish conulariids. This research received support from the SYNTHESYS Project http://www.synthesys.info/ which is financed by European Community Research Infrastructure Action under the FP6 "Structuring the European Research Area" Programme." We thank Martin Valent (Národní muzeum, Prague) for his help with the hyolithid identification and Dr Paul Taylor for linguistic help.

\section{References}

Ausich, W. I., Gil Cid, M. D. \& Domínguez Alonso, P., 2002. Ordovician [Dobrotivian (Llandeillian Stage) to Ashgill] crinoids (Phylum Echinodermata) from the Montes de Toledo and Sierra Morena, Spain with implications for paleogeography of Peri-Gondwana. Journal of Paleontology, 76(6): 975-992. doi: $10.1666 / 0022-3360(2002) 076<0975$

Barrande, J., 1867. Systême Silurien du Centre de la Bohême. Iere. Partie Recherches Paléontologiques. Vol. 3(1). Classe des Mollusques. Ordre des Ptéropodes. Édition de l'auteur. Prague et Paris. XV + 179 pp., 16 pls.

Barreiro, J., 1992. El Museo Nacional de Ciencias Naturales (1771-1935). Doce Calles. Madrid. 509 pp.

Bengston, P., 1988. Open nomenclature. Palaeontology, 31(1): 223-227.

Bouček, B., 1928. Revise ?esk?ch paleozoick?ch Konularíi. Palaeontographica Bohemiae, 11: 1-108, 7 pls.

Bouček, B., 1939. Conularida. In: Schindewolf, O.H. (ed.). Handbuch der Palaozoologie, vol. 2A(5). Verlag von Gerbruder Borntraeger. Berlin: A113-A131.

Delgado, J. F. N., 1897. Fauna Silúrica de Portugal: novas obsevações acerca de Lichas (Uralichas) ribeiroi. Direccão dos trabalhos geologicos de Portugal, Academia Real das Sciencias. Lisboa. 34 pp., 4 pls.

Delgado, J. F. N., 1908. Système Silurique du Portugal. Etude de Stratigraphie Paléontologique. Commission du Service géologique du Portugal. Lisbonne. 247 pp., 8 pls.
Gutiérrez-Marco, J. C., Aramburu, C., Arbizu, M., Bernárdez, E., Hacar Rodríguez, M. P., Méndezbedia, I., Montesinos López, R., Rábano, I., Truyols, J. \& Villas, E., 1999. Revisión bioestratigráfica de las pizarras del Ordovícico Medio en el noroeste de España (Zonas Cantábrica, Asturoccidental-leonesa y Centroibérica septentrional). Acta Geológica Hispánica, 34(1): 3-87.

Gutiérrez-Marco, J. C., Rábano, I., Prieto, M. \& Martín, J., 1984. Estudio bioestratigráfico del Llanvirn y Llandeilo (Dobrotiviense) en la parte meridional de la Zona Centroibérica (España). Cuadernos de Geología Ibérica, 9: 287-319.

Gutiérrez-Marco, J. C., Robardet, M., Rábano, I., Sarmiento, G. N. San José Lancha, M. A., Herranz Araújo, P. \& Pieren Pidal, A. P., 2002. Ordovician. In: W. Gibbons \& M.T. Moreno (eds.). The Geology of Spain. Geological Society. London: 31-50.

Hernández Sampelayo, P., 1915. Fósiles de Galicia. Nota sobre la fauna paleozoica de la provincia de Lugo. Boletín del Instituto Geológico de España, 36: 277-303.

Hernández Sampelayo, P., 1931. Criaderos de Hierro de España. Tomo IV: Hierros de Galicia (volumen 2). Memorias del Instituto Geológico y Minero de España, 37: 561 pp.

Hernández Sampelayo, P., 1942a. Explicación del nuevo mapa geológico de España. Tomo II. El sistema siluriano. Memorias del Instituto Geológico y Minero de España, 2(1): XVII + 592 pp.

Hernández Sampelayo, P., 1942b. Explicación del nuevo mapa geológico de España. Tomo II El sistema siluriano. Memorias del Instituto Geológico y Minero de España, 2(2): 593-848.

Kindelán, V., 1918. Criaderos de hierro de las provincias de Guadalajara y Teruel. Memorias del Instituto Geológico de España, 3: 1-176.

Montero, A., 1989. Los materiales Ordovícicos en el área de Retuerta del Bullaque, sinclinal de Navas de Estena (Ciudad Real). Estudios Geológicos, 45(5-6): 399-407.

Montero, A., 2003. La Paleontología y sus colecciones desde el Real Gabinete de Historia Natural al Museo Nacional de Ciencias Naturales. Monografías del Museo Nacional de Ciencias Naturales 19. CSIC. Madrid. 393 pp.

Perejón, A. \& Gomís, A., 2005. La Geología y sus protagonistas en España desde 1900 a 1974. Boletín de la Real Sociedad Española de Historia Natural (Sección Geológica), 100(1-4): 235-276.

Rábano, I., 1985. Precisiones sobre los trilobites del Arroyo del Acebrón (Ventas con Peña Aguilera, Toledo). Coloquios de Paleontología, 40: 9-17.

Rábano, I., 1989. Trilobites del Ordovícico Medio del sector meridional de la Zona Centroibérica española. Parte I. Yacimientos, bioestratigrafía y aspectos paleobiogeograficos. Boletín Geológico y Minero, 100(3): 307-338. 
Sendino, C., 2007a. Los conuláridos del Museo Nacional de Ciencias Naturales de Madrid. In: O. Cambra Moo, C. Martínez Pérez, B. Chamero Macho, F. Escaso Santos, S. Esteban de Trivigno \& J. Marrugán Lobón. Cantera Paleontológica. Diputación Provincial de Cuenca. Cuenca: 339-347.

Sendino, C., 2007b. Revisión de la colección de Conulariidae de The Natural History Museum de Londres (Reino Unido). PhD. Universidad Complutense de Madrid. 601 pp.

Van Iten, H. T. \& Vyhlasová, Z., 2004. Conulariids. In: B. D. Webby, F. Paris, M.L. Droser \& I.G. Percival (eds.). The Great Ordovician Biodiversification Event. Columbia University Press. New York: 119-123.

Wilson, W. E., 2010. Mineralogical Record. Biographical Archive [on line]. <www.mineralogicalrecord.com> [Seen on 9 July 2010].

Želizko, J. V., 1900. Uber einen neuen Fossilienfundort im mittelbohmischen Untersilur. Verhandlungen fur Kaiserlich-koniglichen geologischen Reichsanstalt, 1900(3): 85-93.

Želizko, J. V., 1901. Einige neue Beitrage zur Kenntnis der Fauna des mittelbohmischen Untersilurs. Verhandlungen fur Kaiserlich-koniglichen geologischen Reichsanstalt, 1901(9): 225-233.

Želizko, J. V., 1902. Weitere neue Beitrage zur Kenntnis der Fauna des bohmischen Untersilurs. Verhandlungen fur Kaiserlich-koniglichen geologischen Reichsanstalt, 1902(2): 61-66.

Želizko, J. V., 1903. Uber das neue Vorkommen einer untersilurischen Fauna bei Lhotka (Mittelbohmen). Verhandlungen fur Kaiserlich-koniglichen geologischen Reichsanstalt, 1903(3): 61-65.

Želizko, J. V., 1905. Neue Beitrage zur Kenntniss der Fauna der Etage Dd1Y des mittelbohmischen Silur. Koniglichen-bohemischen Gesellschaft der Wissenschaften, Sitzungsberichte, 1905(11): 1-7.

Želizko, J. V., 1906a. Uber das erste Vorkommen von Conularia in den Krusna hora-Schichten (Dd1 a) in Bohmen. Verhandlungen fur Kaiserlich-koniglichen geologischen Reichsanstalt, 1906(4): 127-130.

Želizko, J. V., 1906b. Geologicko-palaeontologicke pomery nejblizsiho okoli Rozmitalu. Rozpravy? eske Akademie II, 15(42): 1-26, 2 pls.

Želizko, J. V., 1907a. Zur Palaeontologie der untersilurischen Schichten in der Gegend zwischen Pilsen u. Rokycan. Verhandlungen fur Kaiserlich-koniglichen geologischen Reichsanstalt, 1907(16): 378-382.

Želizko, J. V., 1907b. Untersilurische Fauna von Sarka bei Prag. Verhandlungen fur Kaiserlichkoniglichen geologischen Reichsanstalt, 1907(8): 216-220.
Želizko, J. V., 1909a. Faunistische Verhaltnisse der untersilurischen Schichten bei Pilsenetz in Bohmen Verhandlungen fur Kaiserlich-koniglichen geologischen Reichsanstalt, 1909(3): 63-67.

Želizko, J. V., 1909b. Vorlaufiger Bericht uber einige neue Pteropoden des alteren Palaeozoicums Mittelbomischen. Bohmen Verhandlungen fur Kaiserlich-koniglichen geologischen Reichsanstalt, 1909(16): 1-4.

Želizko, J. V., 1911a. Zwei neue Conularien aus dem alteren Palaozoikum von Bohmen. Jahrbuch fur Keiserlich-Koniglichen geologischen Reichsanstalt, 61(1): 116-118, pl. 9.

Želizko, J. V., 1911b. Neue Pteropoden des alteren Palaozoikum Mittelbohmens. Kaiserlich- Koniglichen geologischen Reichsanstalt. Jahrbuch fur KeiserlichKoniglichen geologischen Reichsanstalt, 61(1): 4152, pls. 3-4.

Želizko, J. V., 1913. Zwei neue Conularien aus dem alteren Palaozoikum von Bohmen. Neues Jahrbuch fur Mineralogie, Geologie und Palaontologie, 1: 116-118, pl. 9.

Želizko, J. V., 1918. Zahadny pteropod v spodnim siluru u Karyzku. ?asopis Národniho musea. Oddíl p?irodov?dn?, 92(4): 177-180.

Želizko, J. V., 1921. Aquivalente der untersilurischen Euloma-Niobe-Tauna bei Plzenec in Bohmen. Videnskapselskapets Skrifter, 2(10): 27 pp., 5 pls.

\section{ARCHIVAL DOCUMENTS}

Archivo del Museo Nacional de Ciencias Naturales (AMNCN). Serie Registros de entrada y salida

CN0239/001. Libros de entradas y salidas de objetos de las colecciones de Geología y Paleontología, 186810-00/1877-00-00.

CN0239/002. Libros de entradas y salidas de objetos de las colecciones de Paleontología, 1877-08-00/189406-29. 
Appendix 1.- Complete inventory of conulariids housed at the MNCN (CSIC), Spain.

Apéndice 1.- Inventario completo de los Conuláridos conservados en el MNCN (CSIC), Spain.

\section{CONULARIID COLLECTION OF THE MUSEO NACIONAL DE CIENCIAS NATURALES, MADRID.}

Family Conulariidae Walcott, 1886

Genus Archaeoconularia Bouček, 1939

Archaeoconularia fecunda (Barrande, 1867)

\section{MNCNI- 20713}

Stratigraphy: Early Llanvirn, Middle Ordovician. Site: NE-V ( $\mathrm{x}=528.860 ; \mathrm{y}=544.960)$ after Rábano (1989), outside Navas de Estena, Ciudad Real (Spain). Collection: Ángel Montero (see Montero, 1989). Acquisition date: 1990.

Genus Conularia Miller in Sowerby, 1821

\section{Conularia splendida Billings, 1866}

\section{MNCNI-37798 and MNCNI-37799}

Stratigraphy: Maquoketa Formation, Richmondian, Upper Ordovician.

Site: $3 \mathrm{Km}$ E Elgin, Fayette County, Iowa (USA). Collection: Sendino \& Van Iten.

Acquisition date: 2007.

Genus Exoconularia Sinclair, 1952

Exococonularia exquisita (Barrande, 1867)

\section{MNCNI-13576}

Stratigraphy: ? Middle Ordovician.

Site: Navas de Estena, Ciudad Real (Spain).

Collection: J. Royo, J. Gómez de Llarena and G.M. Cardoso. Acquisition date: June 1934.

Bibliographical reference: Sendino, 2007a, 2007b.

MNCNI-20571 (mould and countermould)

Stratigraphy: Late Llanvirn. Middle Ordovician.

Site: 15 after Montero (1989), Retuerta del Bullaque, Ciudad Real (Spain).

Collection: Ángel Montero (see Montero, 1989).

Acquisition date: 1989.

Bibliographical reference: Sendino, 2007a, 2007b.

\section{MNCNI-20712}

Stratigraphy: Early Llanvirn. Middle Ordovician. Site: NE-V ( $\mathrm{x}=528.860 ; \mathrm{y}=544.960)$ after Rábano (1989), outside Navas de Estena, Ciudad Real (Spain). Collection: Ángel Montero (see Montero, 1989). Acquisition date: 1990

Exococonularia cf. exquisita (Barrande, 1867)

MNCNI-20568 (mould and countermould)

Stratigraphy: Late Llanvirn. Middle Ordovician.
Site: 15 after Montero (1989), Retuerta del Bullaque, Ciudad Real (Spain).

Collection: Ángel Montero (see Montero, 1989).

Acquisition date: 1989.

Bibliographical reference: Sendino, 2007a, 2007b.

MNCNI-20569 (mould and countermould)

Stratigraphy: Late Llanvirn. Middle Ordovician.

Site: 15 after Montero (1989), Retuerta del Bullaque, Ciudad Real (Spain)

Collection: Ángel Montero (see Montero, 1989).

Acquisition date: 1989.

Bibliographical reference: Sendino, 2007a, 2007b.

\section{Exoconularia? sp.}

\section{MNCNI-20564}

Stratigraphy: Early Llandeilo. Middle Ordovician. Site: Navas de Estena-Retuerta del Bullaque road, km. 10, Ciudad Real (Spain).

Collection: Ángel Montero (see Montero, 1989).

Acquisition date: 1989.

\section{MNCNI-20565}

Stratigraphy: Late Llanvirn. Middle Ordovician.

Site: 16 after Montero (1989). Retuerta del Bullaque, Ciudad Real (Spain).

Collection: Ángel Montero (see Montero, 1989).

Acquisition date: 1989.

Bibliographical reference: Montero, 1989.

\section{MNCNI-20567}

Stratigraphy: Late Llanvirn. Middle Ordovician.

Site: 15 after Montero (1989), Retuerta del Bullaque, Ciudad Real (Spain)

Collection: Ángel Montero (see Montero, 1989).

Acquisition date: 1989.

Bibliographical reference: Sendino, 2007a, 2007b.

Genus Metaconularia Foerste, 1928

Metaconularia cf. imperialis (Barrande, 1867)

\section{MNCNI-20983}

Stratigraphy: Early Llanvirn. Middle Ordovician. Site: Arroyo Acebrón. Ventas con Peña Aguilera, Toledo (Spain).

Collection: Ángel Montero (see Montero, 1989). Acquisition date: 1993 .

Bibliographical reference: Sendino, 2007a, $2007 b$.

Metaconularia? pyramidata (Bronn, 1837)

\section{MNCNI-17345}

Stratigraphy: Lower Palaeozoic (?Ordovician). In case this sample came from Czech Republic, would be from Letná Formation (?). 
Site: Unknown. This specimen resembles Barrande's (1867) Metaconularia consobrina samples from Mte Dravob (Czech Republic), kept as steikerns, with the same sample colour. This origin clashes with the Leo Imperatori's fossil precedence (Iberian Palaeolithic). Collection: Leo Imperatori.

Acquisition date: Beginning 1980s.

\section{MNCNI-04948}

Stratigraphy: Upper Ordovician.

Site: May, Calvados (France).

Collection: Comptoir Géologique de Paris.

Acquisition date: End of 1880s.

Bibliographical reference: Sendino, 2007a, 2007b.

Genus Pseudoconularia Bouček, 1939

Pseudoconularia klouceki (Bouček, 1928) ?

\section{MNCNI-20566}

Stratigraphy: Early Llanvirn. Middle Ordovician. Site: 3 after Montero (1989), Retuerta del Bullaque, Ciudad Real (Spain)

Collection: Ángel Montero (see Montero, 1989).

Acquisition date: 1989.

Bibliographical reference: Sendino, 2007a, 2007b.

Pseudoconularia cf. klouceki (Bouček, 1928)

\section{MNCNI-20570}

Stratigraphy: Late Llanvirn. Middle Ordovician. Site: 15 after Montero (1989), Retuerta del Bullaque, Ciudad Real (Spain)

Collection: Ángel Montero (see Montero, 1989).
Acquisition date: 1989.

Bibliographical reference: Sendino, 2007a, 2007b.

Pseudoconularia nobilis (Barrande, 1867)

\section{MNCNI-13575}

Stratigraphy: Ordovician.

Site: Navas de Estena, Ciudad Real (Spain).

Collection: J. Royo, J. Gómez de Llarena and G.M. Cardoso.

Acquisition date: June 1934.

Bibliographical reference: Sendino, 2007a, $2007 \mathrm{~b}$.

\section{Pseudoconularia sp.}

MNCNI-20563 (Four specimens recorded with the same number)

Stratigraphy: Early Llanvirn. Middle Ordovician. Site: Navas de Estena, Ciudad Real (Spain).

Collection: Ángel Montero (see Montero, 1989).

Acquisition date: 1989.

Indeterminate Conulariidae Walcott, 1886

MNCNI-18212 (Indeterminate fragment)

Stratigraphy: Llanvirn, Middle Ordovician.

Site: Alía, Cáceres (Spain)

Collection: Royo Gómez.

Acquisition date: March 1935

\section{MNCNI-34069}

Stratigraphy: Ordovician.

Site: Almadén, Ciudad Real (Spain).

Acquisition date: End of 19th century.

Bibliographical reference: Sendino, 2007a, $2007 \mathrm{~b}$. 